\title{
Уникнення легеневих ускладнень у післяопераційних хворих
}

Уникнення легеневих ускладнень у хворих в післяопераційний період - особливо актуальна проблема в контексті пандемії COVID-19. За цією темою люб'язно погодився прочитати лекцію Олег Туркот (Oleg Turkot), професор - асистент кафедри анестезіології та реаніматології Університету Джонса Гопкінса (Johns Hopkins University), Балтімор, штат Меріленд, США. За даними американських рейтингів, Університет Джонса Гопкінса посідає 5-те місце з медицини у світі та 1-ше місце з анестезіології серед університетів США, а університетська лікарня 17 років поспіль посідала 1-ше місце серед лікарень США.

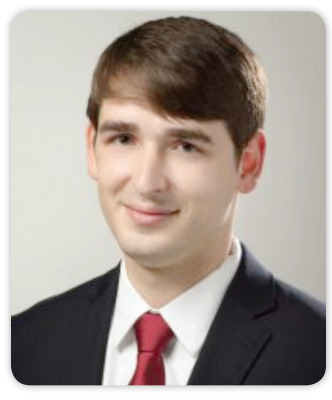

\section{Фактори ризику розвитку}

\section{післяопераційних легеневих ускладнень}

Частота післяопераційних легеневих ускладнень дуже відрізняється залежно від ефективності спостереження за цими ускладненнями. У деяких випадках цей показник може становити 5\%, але в реальності у близько $80 \%$ пацієнтів у післяопераційний період можуть відмічати ті чи інші легеневі ускладнення [1]. Насправді це дуже лякає: як ми можемо ефективно лікувати пацієнтів, якщо в такої великої частки з них можуть розвинутись ускладнення? Найкращий підхід - враховувати фактори ризику. Вважається, що найвищий ризик розвитку легеневих післяопераційних ускладнень виникає при проведенні ургентної хірургічної операції, у пацієнтів віком >65 років, при тривалості операції >3 год, наявності у паці$\epsilon$ нта серцевої недостатності, хронічного обструктивного захворювання легень, при вживанні тютюну протягом останніх 8 тиж, застосуванні інтраопераційної нервово-м'язової блокади тривалої дії, оперативному втручанні на верхній половині черевної порожнини, легенях, голові та шиї, нейрохірургічних операціях. Як показує практика, до факторів ризику також можна віднести проведення загальної анестезії (порівняно з регіонарною та нейроаксіальною), рівень артеріального $\mathrm{CO}_{2}>45$ мм рт. Ст., наявність гострої респіраторної вірусної інфекції, зміни на рентгенограмі грудної клітки до операції, післяопераційне введення назогастрального зонду.

\section{Доопераційний період}

У доопераційний період пацієнт фізично та емоційно готується до оперативного втручання, проводяться всі необхідні попередні огляди, такі як електрокардіографія та дослідження крові, отримується інформована згода. Проводиться бесіда з пацієнтом щодо необхідності відмови від тютюнопаління, здійснюються доопераційні вправи та рання легенева реабілітація, навчання пацієнта маневрам зі збільшення об'єму легень.

Одна з найтяжчих речей, яку можна зробити, - досягти, щоб пацієнт кинув палити. Якщо він не може кинути палити, треба хоча 6 утримуватися від цього протягом щонайменше 8 тиж, адже доведено, що кількість ускладнень значно зменшується, якщо пацієнтам вдається кинути палити [2]. Стратегії відмови від тютюнопаління включають нікотинзамісну терапію (жувальні гумки, нікотинові пластирі, які допомагають пацієнтам уникнути синдрому абстиненції), застосування вареникліну (одного з класичних препаратів, який допомагає досягти найліпшого результату), а також когнітивно-поведінкову терапію. Обговорювати і починати ці стратегії треба якомога раніше, тоді вони ефективні. Зазвичай, говорячи курцю про те, що він має кинути палити, шанси на те, що він це зробить, $<25 \%$, але при застосуванні всього вказаного комплексу заходів вони підвищуються до 45\%.

Ідея доопераційної реабілітації - насправді одна з найефективніших і допомагає значно покращити загальний фізичний стан пацієнтів [3]. Зазвичай хворі перед операцією мають мінімальний рівень функціональних можливостей, після операції він значно знижується, а у реабілітаційний період - поступово повертається до вихідного рівня. Але багато пацієнтів не можуть цього досягнути, навіть якщо їм надано для цього всі можливості. Це період з дуже великою кількістю ускладнень, і багато пацієнтів не можуть виконувати ефективні реабілітаційні заходи [4]. Тому виникла ідея проведення пререабілітації - виконання вправ до операції з метою досягти підвищення сил у пацієнтів, тоді після операціїїх стан погіршиться, але не нижче можливості мати ефективний функціональний рівень, і вони значно швидше повертаються до вихідного рівня.

\section{Приклад 4-тижневої пререабілітаційної програми}

1. Аеробні вправи:

- повільна ходьба, щобдостатньо розігрітися;

- мінімальне аеробне навантаження (ходьба/велосипед) протягом 30 хв з рази на тиждень з помірною інтенсивністю (4-6за шкалою Борга), потім темп ходьби та тривалість потрібно поступово підвищувати. Рекомендується не перевищувати 7-8 за шкалою Борга. Приклад:ходьба з нормальним темпом протягом 5 хв, далі ходьба зі швидким темпом протягом 2 хв, повтор на ту саму тривалість часу.

2. Вправи з опором:

- починати з 1 підходу по 10-12 повторень, кількість підходів $і$ повторень поступово збільшувати до 2 підходів і 12-15 повторень;

- вправи з еспандером/ручними гирями (на грудну клітку, дельmоподібний м'яз, біuеnc, mpuцеnc) та з масою власного тіла (віджимання, присідання за допомогою стільия, згинання біцепсу стегна, згинання литкового м'яза, вправи для пресу на стільці або підлозі).

3. Вправи на гнучкість (кожну вправу виконувати двічі та затримувати щонайменше протягом 20 с) для наступних м'язів: груди, біuеnc, mpuщеnc, квадрицеnc, біцепс стегна, литковий м'яз.

4. Вправи дихальноїрелаксачіі:

- абдомінальнедихання (15хв на день);

- застосування релаксачійного CD (звуки природи, дихальні настанови).

Рекомендується вживати продукти, що містять білок, впродовж 30 хв після завершення вправ.

Навчання з розширення об'єму легень повинно бути проведено до операції з усіма пацієнтами групи ризику та щодо всіх ризикованих операцій і повинно містити усний та письмовий компонент для забезпечення розуміння.

\section{Інтраопераційний період}

В інтраопераційному менеджменті пацієнтів використовуються місцеві та нейроаксіальні техніки, зменшення тривалості операції до >3 год, відміна нейром'язової блокади (додавання антидотів до міорелаксантів наприкінці операції). Загалом нейроаксіальна анестезія дуже ефективна щодо зменшення кількості ускладнень. За даними аналізу 20 досліджень за участю 3006 пацієнтів, коли замість загальної анестезії проводили епідуральну або спінальну анестезію, ризик смерті під час операції або протягом наступних 30 днів знизився приблизно на 29\%. Крім того, ризик розвитку пневмонії був знижений на 55\% (5 досліджень, 400 учасників). Проте ризик розвитку інфаркту міокарда був однаковий для обох методів анестезії (6 досліджень, 849 учасників) [5] 
Щодо тривалості операції: хірурги не повинні поспішати, але, 3 іншого боку, чим довше пацієнт знаходиться під загальною анестезією, тим вищий ризик розвитку ускладнень. Тому пацієнтам із найбільш високим ризиком не повинні проводити довготривалі операції. Слід розглядати можливість поетапних процедур, зробивши все необхідне під час операції і, за можливості, проводити деякі наступні втручання пізніше. Під час проведення операцій у пацієнтів дуже високого ризику, в яких $\epsilon$ ризик виникнення ускладнення, немає можливості втрачати час і приділяти увагу навчанню інтернів та іншого медичного персоналу: навчати треба поза операційною або не на пацієнтах групи високого ризику.

На рахунок міорелаксантів: слід уникати застосування паралітичних препаратів довготривалої дії. Зрозуміло, що гіповентиляція пов'язана зі збільшеними легеневими ускладненнями у пацієнтів. Під час операцій при загальній анестезії рекомендовано проводити моніторинг скорочень - стандартне обладнання для усіх загальних анестезій для оцінки м'язового тонусу до екстубації. Під час операції, коли хірургам потрібно отримати більшу міорелаксацію, щоб мати доступ, наприклад, до черевної порожнини, або щоб наприкінці операції ефективно затягнути шви, треба розуміти рівень міорелаксації перед тим, як давати повторні дози міорелаксантів. При екстубації теж обов'язково потрібно знати, наскільки сильною $\epsilon$ міорелаксація, тому використання таких моніторів $\epsilon$ надзвичайно важливим.

\section{Післяопераційний період}

Післяопераційний догляд включає контроль болю, ранню мобілізацію пацієнтів, розширення легень. Ефективний контроль болю має першочергове значення у післяопераційній палаті, дозволяє пацієнту мобілізуватися рано, дихати глибоко і особливо важливий саме при операціях на верхній половині черевної порожнини та на легенях.

\section{Як довести, що ці підходи є справді ефективними?}

Перш за все слід розглянути можливість місцевої та епідуральної анестезії замість традиційної опіоїдної монотерапії, а також застосовування допоміжної терапії парацетамолом, нестероїдними протизапальними препаратами, габапентиноїдами (останні дуже ефективні щодо зниження болю, але їх не рекомендовано призначати при операціях на коліні через більшу седацію, неможливість виконувати інші частини лікувального протоколу і в результаті збільшення кількості легеневих ускладнень). Призначення опіоїдів не повинно бути стандартним цілодобовим, а тільки за показаннями, при сильному болю. Для визначення інтенсивності болю треба використовувати шкалу болю з чіткими визначеннями, зрозумілими для пацієнта, наприклад «біль 1» відповідає незначному зубному або головному болю, «біль 4-5» - при переломі кісток, тобто достатньо сильний, але не повністю критичний, «біль >6»після тяжких травм, великих розрізів і нарешті «біль 10» — повністю неймовірний біль, наприклад при вагінальних пологах, нападі сечокам'яної хвороби. Підхід до пацієнтів повинен бути індивідуалізованим і таким, аби забезпечувати саме те, що для них $\epsilon$ найефективнішим. Якщо пацієнт не може говорити - треба орієнтуватися на його фізіологічні показники. 3 іншого боку, якщо пацієнти проявляють елементи катастрофізації болю або соматизації симптомів, лікування повинно повністю відповідати ситуації. У цих випадках не потрібно призначати опіати в більшій кількості, а застосовувати інші препарати, які можуть бути ефективними.

Рання мобілізація - одна з найважливіших речей, яку можна зробити післяопераційним пацієнтам. Показано, що рання примусова мобілізація пацієнтів, які перенесли операцію з приводу раку шлунково-кишкового тракту, сприяє зниженню частоти післяопераційних легеневих ускладнень на 62\% [6]. Мобілізація пацієнтів повинна здійснюватися в комплексі з реабілітологом. При цьому пацієнти повинні отримувати ефективний контроль болю, катетери повинні бути встановлені у безпечному місці. Рухатися - не означає бігти марафон. Пацієнт може встати з ліжка, дійти до крісла і повернутися в ліжко або пройтися по палаті. На 2-й день обсяг рухів слід збільшувати і т.д. Чим раніше пацієнт почне рухатися, якщо це буде безпечно, тим менше виникатиме ускладнень.

Одна з найважливіших речей, яку дуже часто не використовують достатньо ефективно у багатьох лікарнях, - маневри з роз- ширення легень. Мета розширення легень - збільшити їх об'єм через сильну інспірацію, що означає, що пацієнту потрібно вдихати, а не видихати. Треба стимулювати кашльовий рефлекс, який би дав можливість мокротинню, яке знаходиться в глибині легень, повертатися назад. Суттєве зменшення кількості легеневих ускладнень у післяопераційних пацієнтів доведено у великій кількості Кокрейнівських метааналізів. Це $\epsilon$ стандартною частиною майже усіх протоколів ERAS (Enhanced Recovery After Surgery - прискорене (покращене) відновлення після операції), інтервенцією з низьким ризиком і низькою вартістю.

\section{Приклад навчання пацієнта}

Як використовувати спонукальний спірометр?

Ваш лікар визначив маркер для вас. Ваша мета - затримувати пістон (або кульку) на вашому маркері якомога довше з кожним вдихом.

1. Сядьте та візьміть у руки свій спірометр.

2. вдихніть глибоко та видихніть.

3. Стисніть мундитук губами. Впевніться, що губи щільно стискають мундитук.

4. Вдихніть повільно через мундитук (як ви би тягнули повітря через трубочку):

- притримуйтеся індикатора діапазону (кульки);

• вдихайте, поки кулька не досягне відмітки.

5. Затримайте подих на 3 с іпотім видихніть.

Які пацієнти отримують найбільшу користь від таких заходів?

Це пацієнти з вихідним ателектазом, які проходять високоризиковані операції (торакальна хірургія, операції на верхній частині живота, хірургія аорти та інших великих судин черевної порожнини). Також можлива потенційна користь у пацієнтів після COVID-19, хоча ефективність не була чітко перевірена. Усі ці пацієнти повинні бути ретельно обстежені із застосуванням мультидисциплінарного підходу.

Стандартний підхід до терапії спонукальною спірометрією передбачає: 1) початок щонайменше за 1 тиж до і з продовженням протягом щонайменше 2 тиж після операції; 2) щогодинні сеанси у стані денної бадьорості; 3) кількість повторень: 10 вдихів за сеанс 3 подальшим відкашлюванням. Це дуже безпечна інтервенція, тому можна без додаткових обстежень підвищувати навантаження 3 огляду на стан пацієнта.

Пацієнта необхідно навчити притримувати хірургічним бандажем (чи подушкою) живіт для уникнення дискомфорту [7]. У нашій лікарні пацієнти після COVID-19 відновлюють легені за цією методикою впродовж 8 тиж.

Таким чином, за допомогою всіх цих технік можна досягти зниження частоти легеневих ускладнень у післяопераційних пацієнтів.

Відео лекціі-за посиланням: https://www.youtube.com/watch?v=m/5D9VJdIW0

\section{Список використаної літератури/References:}

1. Fisher B.W., Majumdar S.R., McAlister F.A. (2002) Predicting pulmonary complications after nonthoracic surgery: asystematic review ofblinded studies. Am.J.Med., 112(3):219-225. doi: 10.1016/ s0002-9343(01)01082-8.

2. Jung K.H., Kim S.M., Choi M.G. et al. (2015) Preoperative smoking cessation can reduce postoperative complications in gastric cancer surgery. Gastric Cancer, 18: 683-690.

3. Carli F., Scheede-Bergdahl C. (2015) Prehabilitation to enhance perioperative care. Anesthesiol. Clin., 33(1): 17-33. doi: 10.1016/j.anclin.2014.11.002.

4. Sultan P., Hamilton M.A.,Ackland G.L. (2012) Preoperative muscle weakness as defined by handgrip strength and postoperative outcomes: a systematic review. BMC Anesthesiol., 12: 1. doi: 10.1186/1471-2253-12-1.

5. Guay J., Choi P., Suresh S. et al. (2014) Neuraxial blockade for the prevention of postoperative mortality and major morbidity: an overview of Cochrane systematic reviews. Cochrane Database Syst. Rev., 2014(1): CD010108. doi: 10.1002/14651858.CD010108.pub2.

6. van der Leeden M., Huijsmans R., Geleijn E. et al. (2016) Early enforced mobilisation following surgery for gastrointestinal cancer: feasibility and outcomes. Physiotherapy, 102(1): 103-110. doi: 10.1016/jphysio.2015.03.3722.

7. Armstrong C.0. (2017) Post-op incentive spirometry: Why, when, \& how. Nursing, 47(6): 54-57. doi: 10.1097/01.NURSE.0000516223.16649.02. 